\title{
THE DISCURSIVE INTERACTION BETWEEN REPRESENTATIVE MAN AND WOMAN IN MAPPETTU ADA MARRIAGE PROPOSAL IN BUGINESE SOCIETY (A SEMIOTIC APPROACH)
}

\author{
Zulkhaeriyah \\ Email:hery_zulkhaeriyah@yahoo.com \\ English Language Studies, Hasanuddin University
}

\begin{abstract}
Abstrak
Interaksi diskursif meliputi dialogism dan parallelism. Penelitian ini bertujuan untuk menganalisa interaksi diskursif yang muncul pada acara Mappettu ada. Penelitian ini menggunakan metode deskriptif kualitatif yang menunjukkan penggambaran dan elaborasi secara sistematis tentang interaksi apa saja yang terdapat dalam acara Mappettu ada. Data ini diperoleh dari ujaran dalam Mappettu ada yang diujarkan oleh perwakilan laki-laki dan perempuan yang diselenggarakan dalam acara Mappettu ada. Hasil dari data menunjukkan bahwa acara Mappettu ada diselenggarakan dengan diadakannya pertemuan secara adat antara perwakilan pihak laki-laki dan perempuan dengan maksud untuk mendiskusikan tentang tanra esso (hari pernikahan), sompa (mahar), balanca (uang belanja). Hasil lain penelitian ini adalah adanya interaksi diskursif yang muncul dalam Mappettu ada yaitu dialogisme dan parallelisme. Bentuk parallelism yang muncul dalam acara Mappettu ada adalah parallelisme interaksi.

Kata kunci: Mappettu ada, interaksi, parallelism.
\end{abstract}

\begin{abstract}
The discursive interaction consists of dialogism and parallelism. This research is aimed to analyze the discursive interaction that occurs in Mappettu ada event. The researcher employed descriptive qualitative method, shows a description and elaboration systematically what the interactions happened in Mappettu ada event. The data were taken from text of Mappettu ada who utterred by the representative of man and woman which was held in Mappettu ada event. The result of the data shows that the
\end{abstract}


Mappettu ada is carried out through two representative of man and woman held the ceremonial custom meeting in order to discuss about tanra esso (the day of marriage), sompa (dowry), balanca (expenses/money for celebrating the marriage). Other result is the discursive interaction that occurs in Mappettu ada event are dialogism and parallelism. The form of parallelism which occurs in Mappettu ada event is interactional parallelism.

Keywords: Mappettu ada, interaction, parallelism.

\section{A. Introduction}

Interaction is a kind of action that occurs as two or more objects that have an effect upon one another. The idea of two-way effects is essential in the concept of interaction as opposed to a one way-casual effect. Interaction is a part of communication, for example two or more people talk to each other, or communicate among groups, even organizations. U.S Army (1983) argues that communication is the exchange and flow of information and ideas from one person to another. It involves a sender transmitting an idea, information, or feeling to a receiver. Effective communication occurs only if the receiver understands the exact information or idea that the sender intended to transmit.

Communicating with others involves three primary steps. There are thought, encoding, and decoding. Thought is all information exists in the mind of the sender. This can be a concept, idea, information, or feelings. Next, encoding is a message which be sent to a receiver in words or other symbols. Lastly, decoding is the receiver translates the words or symbol into a concept or information that can be understood. ${ }^{1}$ In communicating each other, everybody needs a medium language. Through language, people can interact and convey their thought, desires, ideas, wishes, and feeling to other people. Therefore, it is regarded that everything in this world has their own function, included language. This kind of function can be seen in education. For example, to obtain knowledge, language is the most important media because there is no education without it. Therefore, it is useful to learn language because communicating is one activity of human being that differentiates from other beings.

Generally, culture consists of three levels; they are knowledge, behavior, and belief. Knowledge and behavior are reflected in language. The culture of a country basically reflects the belief, hope, the way of life, ideology and politics of the country. These aspects explicitly and implicitly are explained by the language. The way someone speaks reflects the culture he/she has. Any knowledge or science is studied and developed using that language. Language is also used to introduce our culture especially to young generation. The recent generation inherits culture, tradition, and behavior from the ancestors, so that culture cannot be totally disappeared.

${ }^{1}$ Cook, Gay. Discourse. (Oxford: Oxford University Press, 1989). 
This research is investigated by using semiotic approach, where see the text as denotational text. Semiotics is the study of sign and everything related, so it is possible to some entities treating as a meaningful sign. Based on Pierce ${ }^{2}$ study of sign or symbol is a language study because language is a tool to interpret meaning which is has a situational aspect, such as some texts cannot be understood as one word or sentence only, but it looks as one unit that contains meaning with values and powers itself. Semiotics analysis will become a study to analyze the text because one way to know meaning of the text use semiotics approach which is examining system of signs. Text Mappettu ada is a part of culture where there is interconnection of signs, codes, and texts that makes up a culture. ${ }^{3}$ They assume that culture, in semiotics, is interconnected system of daily living that is held together by the signifying order (signs, codes, texts).

Text is a sign system strong or arbitrariness, proposing the autonomy of language in relation to reality. Text emphasis or internal structures and thus does not reflect reality but rather constructs is. It is conventional with an emphasis on the type's index and symbol. Text is any message preserved in a form whose existence is independent of both sender and receiver. Text become socially constructed and is outcomes of social actions. So that texts are materializations of what is at issue or what is being talked about. ${ }^{4}$

Texts are forms of exchanging meaning, an 'interaction between speakers' or dialogue. ${ }^{5}$ Texts are always created in particular situations and hence must always be understood in the perspective of context. According to Halliday and Hasan, texts include 'non-verbal goings on' and, consequently, texts must be interpreted in the context of the situation or in the total 'environment in which the text unfolds. ${ }^{6}$ Texts are artefacts 'produced within specific contexts. ${ }^{7}$

Pierce $^{8}$ said that text is connected to context, means the text is related to the situation and condition in the reality. In a mediated approach to ritual text, the concept of indexicality is used. This concept was proposed by Pierce ${ }^{9}$ to show the relation between sign and object that is based on existential relation. Later, Silverstain used

${ }^{2}$ Pierce, C. Sanders. Logic as Semiotics: The theory of Sign. In Philosophical writings of Pierce. (NewYork: Dover Publications, INC, 1955).

${ }^{3}$ Danessi and Perron, Pesan, Tanda, dan Makna: Buku Teks Dasar Mengenai Semiotika dan Teori Komunikasi. (Yogyakarta: Jalasutra, 1999), h.366

${ }^{4}$ Kress, G. Literacy in The New Media Age. (London: Routledge , 2003). h.47

${ }^{5}$ Halliday, M.A.K. An Introduction to Functional Grammar. (London: NewYork: Edward Arnold, 1985). h. 11

${ }^{6}$ Halliday, M.A.K. An Introduction to Functional Grammar

${ }^{7}$ Carrington, Victoria. I write, therefore I am: Texts in the City. (Sage Journals. American Political Resources, 2009), h.16

${ }^{8}$ Pierce, C. Sanders. Logic as Semiotics: The theory of Sign...

${ }^{9}$ Pierce, C. Sanders. Logic as Semiotics: The theory of Sign... 
indexicality as the level of mediating denotational text or the statement text and interactional text or the text that answer the existing question of what really happen.

Bugis language as the mother tongue of Bugis people is a tool of communication which is very effective to communicate each other in that social. Bugis language is used in many interactions as Mattulada ${ }^{10}$ says:

"Bahasa Bugis pada zaman dahulu kala menjadi bahasa untuk semua kegiatan kebudayaan orang Bugis. Bahasa Bugis dipergunakan dalam menyebarkan agama dalam perdagangan, pertanian, dan ilmu kesusasteraan".

(Bugis language in ancient period becomes a universal language for all Buginese cultural activities. It is used to spread religion through trade, agriculture, and literature).

Bugis culture is one of the local cultures in Indonesia and it is predominant in South Sulawesi. The Bugis culture has many unique things. There is lontaraq (a written manuscript) or other forms of literature such as ancestor's message, folklore, and also some ritual such as marriage ceremony. Marriage is the ceremony of being united to a person of the opposite sex as husband or wife in a consensual and contractual relationship recognized by customary law. In Buginese society, especially in Buginese Bone, called mappabbotting which means doing the ceremony. While the term marriage in Buginese society called Siala which means take one another. Thus, marriage is a reciprocal bond between two people in different sex to establish a partnership. ${ }^{11}$

In the view of Buginese people, marriage not only brings two persons together in the marital relationship, but marriage is a ceremony that aims to unify two great families become closer or in Buginese called mappasideppe mabelae which means much closer. That ritual activities are inherent succession and these activities are done by Buginese Bone people who still maintain their custom. Nowdays, it is still unmarked to Buginese people to do this ritual because it contains values that are full of meaning, in order to build a harmonious and lasting relationships for bride and strengthen the relationship of two families.

In Bugis culture, there are three steps before doing marriage ritual ceremony, according to secretary of saoraja custom institute of Bone. There are pre marriage, marriage, and post marriage. ${ }^{12}$ This research explains only on pre marriage. It consists of mappesek-pesek, mammanu-manu, madduta, Mappettu ada and akad nikah.

The first step is Mappesek-pesek / mammanu'-manu' (looking for informations) is done by the elder of the family or the one who become representative of the family to looking information about the woman who wants to be proposed. In this stage, the representative asks directly to woman's family. In this case, the parents

${ }^{10}$ Mattulada. Latoa, Suatu Lukisan Analisis terhadap Antropologi Politik Orang Bugis. (Yogyakarta: Universitas Gajah Mada Press, 1975). h. 8

${ }^{11}$ Pelras, Christian. The bugis. (Cambridge USA: Blackwell Publisher, 1996), h.178

${ }^{12}$ Najamuddin, Andi. Ada Silappa. (Bone, 2006) 
of the women ask whether the woman is still available to be proposed. In other word, there is no someone who propose her before. The second step is Madduta (marriage proposal). After doing the mappesek-pesek, there is next step that must be done; it called Madduta (marriage proposal). In this step, delegate from man side go to woman house to explain their purpose officially. The woman side is inviting their closes family to considerate the proposal from the man side. Thus, in this step is only attended by two or three people. After the group of To Madduta (delegate) comes, then they are accepted by the woman side and directly explain the reason or aim for coming. If the woman side accepts their aim then it will be continued to the next stage. Mappettu ada (making some final agreements). This is the final step before doing a marriage in the Buginese culture. In Mappettu ada (marriage agreement), both man and woman families bunch a promise as agreement that have been done before. Hence, in this stage, they discuss about tanra esso (the day), dui balanca (expenses) and mahar (dowry). From the three steps above, the researcher focuses on the last step is Mappettu ada.

There are some researchers who have done research on marriage. Cawung ${ }^{13}$ focused on discourse analysis in Madduta with the title Analisis Wacana pada Madduta. He interested in analyzing the discourse and speech act. He explained that in Madduta there is an interrelation between the forms and meaning of the speech act. Another researcher is from Takwa ${ }^{14}$ with the title Tuturan Ritual Mowindahako pada etnis Mekongga Kolaka (pendekatan Linguistik Antropologi). In his research he elaborates the speech forms in Mekongga ritual such as parallelism, repetition, metaphor, and symbolic. He shows us what forms that occur in the data. He also describes paralellism in sound level. Also, Putri ${ }^{15}$ with the title Pemberian Sompa Dalam Sistem Perkawinan Masyarakat Bugis. In this research, the researcher mentioned all the process of the marriage in Buginese from the preparation of the premarriage until the post of marriage without explaining the detail of each part.

Another research related to Mappettu ada was done by Marwana, ${ }^{16}$ with the title Dampak Sosial Tradisi 'Mappettu ada' di desa Cilellang Selatan Kecamatan Mallusetasi Kabupaten Barru. She analyzed the social effect of Mappettu ada tradition in Barru regency. She used descriptive qualitative method to gain data and information. So the researcher observed and interacts with the society and also interviewing them. And the results are Mappettu ada is hereditary tradition before wedding ceremony. And there are some positive and negative effect which is positive

2001)

${ }^{13}$ Cawung, Rivai. Analisis Wacana pada Madduta. (Makassar: Hasanuddin University,

${ }^{14}$ Takwa. Tuturan Ritual Mowindahako Pada Etnis Mekongga. (Makassar: Hasanuddin University, 2014)

${ }^{15}$ Putri, Ingrid. Pemberian Sompa Dalam Sistem Perkawinan Masyarakat Bugis. (Makassar: Hasanuddin University, 2011)

${ }^{16}$ Marwana, Andi. Dampak Sosial Tradisi "Mappettu ada” Di Desa Cilellang Selatan Kecamatan Mallusetasi Kabupaten Barru. (Makassar: FIS UNM, 2016) 
effect is kinship system and deliberation, while the negative effects are disorganization and prestige. Hardianti ${ }^{17}$ with the title Adat Pernikahan Bugis Bone Desa Tuju-Tuju Kecamatan Kajuara Kabupaten Bone dalam Perspektif Budaya Islam shows that marriage ceremony in Bugis Bone consists of three steps, pre marriage, marriage and post marriage. These activities are sequential and should not be exchanged.

The previous researchers discuss the parallelism in sound level, while the present researcher develops the idea by focusing on denotational text to discuss about parallelism in discourse level. The outcome is expected to develop theory of interaction related to Mappettu ada event.

\section{B. Research Methodology}

\section{Research Design}

The research method that used in this research was descriptive qualitative. This qualitative method is chosen because it is one way to elaborate the semiotic. ${ }^{18}$ The results of this research showed a description and elaboration systematically what were the interactions happened in Mappettu ada event.

\section{Source of Data}

The data of this research were taken from text of Mappettu ada which was held in marriage ceremony in Buginese at Bone regency. The speakers in Mappettu $a d a$ sometime used some lexical word of Bugis language that did not use any more in everyday life. Mappettu ada ritual contains of communication exchange, because there is a greeting between sender (host/woman's family) and receiver (guess/man's family), There is also an question and answering from each side. Such the host is asking the aim of the arrived of guess, and also asking the day to celebrate the party from guess to host, etc.

\section{Procedures of Collecting Data}

The techniques of collecting data that used in this research were; the researcher recorded the speech of Mappettu ada in Bugis wedding ceremony which was delivered by a person who was expert in producing that speech, means from the representative of man and also representative of woman; and the researcher interviewed the expert or the speakers from Mappettu ada ritual to collect good translation from the speech that had been uttered by the speakers which used uncommonly words that cannot be understood by the researcher.

\section{Techniques of Analyzing Data}

In order to analyze the data, the researcher did several steps as follows:

a. The dialogue of Mappettu ada that had been recorded was transcribed. The writer listened and wrote down the text carefully.

\footnotetext{
${ }^{17}$ Hardianti. Adat Pernikahan Bugis Bone Desa Tuju-Tuju Kecamatan Kajuara Kabupaten Bone dalam Perspektif Budaya Islam. (Makassar: UIN Alauddin, 2015)

${ }^{18}$ Hoed, Benny H. Semiotik \& Dinamika Sosial Budaya. (Jakarta: Bambu Community, 2011).
} 
b. The dialogue from Bugis language was translated using morpheme by morpheme translation, and then it was translated using contextual translation.

c. Analyzing the narrating and narrated event that occurs in the interaction of Mappettu ada event.

d. Analyzed the discursive interaction which involves the analysis of dialogism, parallelism, identity construction, and metapragmatic talk.

\section{Research Findings}

1. Discursive Interaction

In analyzing the discursive interaction, the researcher analyzes it by applying denotational text. Denotational text occurs on some phenomena such as narrating and narrated event, dialogism, interactional parallelism, and metapragmatic talk. All phenomena will be explained as follows;

\section{a. Narating Event}

Narating Event occurs in Mappettu ada event. Narrating event is a preparation to the narrated event. In this Mappettu ada, it is based on the way of representatives inform his intention based on rule of custom and religion. It is especially a custom in Buginese and a religion of Islam. It is happen in speech of representative of woman in utterances (59) - (65) as follows;

W1:

59. Narimakkuannanaritu ripomenasai ta-patallei majjajareng Therefore pre-hope $2^{\text {nd }}$ sing-decribe orderly

$$
\begin{array}{ll}
\text { hajja menasa } & \text { akkattata, } \\
\text { purpose hope } & \text { aim- } 2^{\text {nd }} \text { sing, }
\end{array}
$$

Now listen to their purposes

60. barakkuaiaga tapattupui ri ade, so that $2^{\text {nd }}$ sing-climb up in costum tapasanrei ri syara, $2^{\text {nd }}$ sing-responsibility in Islam low

follow to the costume and the Islam law

$\begin{array}{lll}\text { 61. tapakkatenniwi } & \text { ri ada tongeng, } \\ 2^{\text {nd }} \text { sing-hold on to } & \text { in }\end{array}$ hold on the truthiness

62. natomattangnga rirapangnge tapattarettei riwari e, pref-look-1 ${ }^{\text {st }}$ plu in-past $\quad 1^{\text {st }}$ plu-rank (social order of society) look at the previous event and follow the requirements

63. narialana peppegau riabiasangnge, take-able conclusion as habit, 


\section{concluded as our habit}

64. namuka sagala sagala memeng, so that unknown unknown yes

because it is a secret

\begin{tabular}{|c|c|c|}
\hline $\begin{array}{l}\text { 1yaparitu } \\
\text { that is }\end{array}$ & $\begin{array}{l}\text { nasagala } \\
\text { known }\end{array}$ & $\begin{array}{l}\text { engkapi } \\
\text { exist }\end{array}$ \\
\hline
\end{tabular}

\section{but it is not secret again it it has been told}

In some utterances above, the narrating event is identified by some utterances that are uttered by speaker to tell something which he wants to tell about. The representative of woman requests at the time towards the representative of man to inform their intension because the speaker as the representative of man wants to reconfirm something that has not informed yet.

The phrase "ada tongeng" (truth word) in utterance (61) shows a timeless activity which it becomes rules in past, present, and future time for Buginese people. And the utterance (63) "narialana peppegau riabiasangnge" (concluded as our habit) also timeless, where it is based on behavior in past, present, and future. Hence, ada tongeng (truth word) and riabbiasangnge (habit), they are used to be rule of Buginese society in conducting formal speech.

Utterances (64) and (65) mean that knowledge known after it is revealed. Language reveals thoughts. And this though is a speaker intention. The word "sagala" means secret. Speaker intention firstly is secret which has hidden in the speaker's mind. Then, it becomes something known if the secret is revealed through language. This case is a signal of narrating event in which speaker uses language to tell his intention.

\section{b. Narrated Event}

Narrated event also occurs in Mappettu ada event. It is happen in speech of representative of man in some utterances as follows;

W2:

209. Nasaba rimakedanna alena ustaz,

Because pref-said he mufti

As Ustad said

210. mua $\quad$ luttu mallumpajang uki sipotanrae
although fly everywhere
silolongeng mua
met
wherever we go, we will meet if we are destiny


In those utterances, the speaker retells what has been said by the representative of man. There is a Buginese proverb related to mate case which states that although human beings are separated, they will be met based on their destiny.

In narrated event, the researcher finds the using of metapragmatic talk which is signaled by phrase "rimakkedanna" (said). This phrase represents what is being said by others. Narrated event is indicated by the pharse "rimakkedanna alena ustaz"(said by mufti) in utterances 209. This indication is a proof that the woman representative agrees with representative of man about the mate.

\section{c. Dialogism}

The researcher explains about the dialogism phenomenon among speech that conducted by three speeches from representative of woman and two speeches from representative of man. Those speeches contain questions such as asking and giving information from representative of woman to the representative of man or in another turn.

That question occurs between whole part of speech that uttered by representative of man and representative of woman. The answer is not directly responded by those representative like when someone asking question in general. That question firstly occurs in monolog and the answer is also in monolog by another representative. But in that monolog, it can be paired between question from representative of woman with the answer from representative of man or in another turn. It happens on the process of dialog. In following presentation below, the researcher shows first dialogism as follows;

W1:

59. Narimakkuannanaritu ri-pomenasa-i tapatallei majjajareng

Therefore pre-hope-suff describe pre-orderly

$\begin{array}{lll}\text { hajja } & \text { menasa } & \text { akkattata, } \\ \text { purpose } & \text { hope } & \text { aim- } 2^{\text {nd }} \text { plu }\end{array}$

Now listen to their purposes

In utterance (59) the speaker uses sentence "ripomenasai tapatallei majjajareng hajja menasa akkatata" (please tell your purpose), the using of word "ripomenasai" comes from basic word "menasa" means hope and it is added with prefix $r i$ and suffix $i$. The adding of prefix and suffix change the function of that word, it becomes imperative that means "I ask you to". This is a sign that the representative of woman asks to the representative of man to explain their purpose for coming in that event. This is a first dialogism which contains asking information from first speech.

After the speaker of woman close their speech, the representative of man conducts his speech. In his monolog, he inserts the answer of the question from the speaker of woman. He says that he comes to bring the proposal of a man namely 
Tuan Afero Harahap, S.H, M.H. Those answers are in utterances (123) and (124), there are:

L2:

$\begin{array}{ll}\begin{array}{c}\text { 123. naiyya hajja } \\ \text { now engkae }\end{array} & \text { koritu kiwawang } \\ \text { purpose that is } & \text { Deic brought } \\ \text { rilalenna iyya essoe } & \\ \text { in } & \text { this day } \\ \text { And what our purposes today } & \end{array}$

$\begin{array}{lllll}\text { 124. iyanaritu } & \text { engkanna } & \text { koritu } & \text { anak-ta } & \text { maelo } \\ \text { is } & \text { there is } & \text { Deict } & \text { son } & \text { sing } \\ \text { riwatakeng } & \text { duta } & & & \\ \text { inform } & \text { proposal } & & & \\ \text { is delivering our son's intension } & & \end{array}$

The answer of the question of representative of woman is in utterance (124) with saying "iyanaritu engkanna koritu anak ta maelo riwatakeng duta" (is delivering our son's intension).

\section{d. Interactional Parallelism}

In presentations below, the researcher will explain an interactional parallelism. Interactional parallelism is the interaction in which a speaker gives his speech then that speech is uttered again or repeated by other speakers with style or variation in uttering those utterances of the other speakers. Based on data that researcher has, it will be shown the interactional parallelism as follows;
174. barakkuammengi natarimaki sibawa madeceng hope receive $-1^{\text {st }}$ plu with good

We do hope to the honorable that our intension can be responded happily.

Then, that utterance is repeated by the representative of woman in third speech.

$\begin{array}{lllll}\text { 231. engkai } & \text { ritu } & \text { ritarima } & \text { sibawa } & \text { madeceng. } \\ \text { Is } & \text { deic } & \text { pref-accept with } & \text { pref-well }\end{array}$

\section{So that, your intension is acceptable}

In sentences above, the repetition occurs in phrase "natarimaki sibawa madeceng" (he accepts us well) in utterance 174 and "ritarima sibawa madeceng" (we accept well) in utterance 231. By the utterance 174, the main point is "natarimaki" the root of that word is "tarima" means accept or receive. In adding of prefix " $n a$ " it refers to representative of woman, and suffix " $k i$ " refers to representative of man. It means that the representative of man as a speaker hopes that they will be accepted well. And it is repeated by the representative of woman 
by saying "ritarimai sibawa madeceng (we accept him well)" in utterance (231). The main point is also in word "ritarimai" where the root is "tarima" means accept or receive. In adding of prefix " $r i$ " it refers to the representative of woman and the suffix " $I$ " is refers to representative of man. It means, the representative of woman receives well the representative of man.

\section{Discussions}

Data shows that in Mappettu ada event, there are three speeches of representative of woman and two speeches of representative of man in. From all speeches, there is dialogism happen where one of speaker asking request information and other speakers give or serves information. In requesting and giving information, there are four processes of dialogism.

There are, firstly, the representative of woman asking information related with the coming of representative of man in first speech. It is answered by the representative of man by saying his purpose. Secondly, the dialogism includes request happens on second speech that the representative of man hopes that their coming will be received well, and responded by The representative of woman. Thirdly, the dialogism of asking information happens in third speech that the representative of woman asks the representative of man to inform the agreement that have been decided before and responded by the representative of man. Fourthly, the representative of man requests or asks information to the representative of woman to cite the day. It is responded by the representative of woman.

The data shows that the dialogue between representative of man and representative of woman is a process of dialogism. Dialogue in general is the communication between persons who hold precisely the same views on a particular subject. ${ }^{19}$ This theory means the dialogue activity involves between persons who take a role as the one giving information and others taking a role as the one receiving information. The time of speaking between speaker and listener is soon responded.

In the researcher's data, when the first speaker utters his speech, he delivers it in monologue way. The second speaker also utters his speech in the same way. That is in monologue way. Related to the theory from Bakhtin, ${ }^{20}$ about Dialogism, it is as follows;

All language - indeed, all thought - appears as dialogical. This means that everything anybody ever says always exist in response to things that have been said before and in anticipation of things that will be said in response. In other words, we don't need speak vacuum. All language (and the ideas which language contains and communicates) is dynamic, relational and engaged in a process of endless redescriptions of the world.

${ }^{19}$ Swidler, Leonard. What is dialogue. (Journal of Ecumenical Studies. Dialogue Institute,

${ }^{20}$ Bakhtin, Michael. The Dialogic Imagination. C.E.M. Holquist, transl. Austin: University of Texas Press, 1981) 
That theory describes that in someone's thought occur dialogue before the responding is uttered. It means that the dialog exist in one person especially in person thought. The researcher uses the term dialogism from Bakhtin ${ }^{21}$ and relates to the dialogue definition by Swidler. ${ }^{22}$ So, dialogism involves the dialogue between two or more persons.

Based on the researcher's data exist the process of dialogue which is different in common way. The differences occur due to the first speaker conducting his speech firstly in monolog way. Then the second speaker conducts his speech in monolog way also. However, the second speaker delivers his monolog tends to as a response toward the first speaker's monolog. This also happens in another monolog which also tends to a response toward another monolog. In this process occurs dialogue between first speaker monolog and second speaker's monolog.

The researcher also wants to show the theory of Roman Jakobson's theory ${ }^{23}$ about parallelism. It is that "poetic function projects the principle of equivalent from the axis of selection into the axis of combination". One of the principles of equivalence is parallelism. However, parallelism that is introduced by Jakobson ${ }^{24}$ only describes how in one text experiences repetition formed parallelism and that repetition exists in similar text. Whereas, in the researcher's data shows the difference.

From the data, parallelism that exist in Mappettu ada event occur when the representative of man repeat the utterances of representative of woman or in another turn. Related to Jakobson ${ }^{25}$ theory of parallelism, he says that the parallelism is repetition with variation which one thing said twice or more by one person.

Contrast with it, some speeches in Mappettu ada is uttered by a person and repeated by another in different text or utterances. So the theory of Jakobson ${ }^{26}$ develops that there is phenomenon namely interactional parallelism. Interactional parallelism here is aimed to validate a marriage. It means the repetition use as a sign that the speech of speaker is agreed by the hearer when he repeats the speech.

Relating to marriage process in Buginese and in England, there is a difference both of regions due to the cultural aspect. The different culture yields some different attitudes toward holding marriage ceremony. Marriage in England is influenced by Christen. This religion affects the society's ways of thinking. The discussion about the marriage preparation do not held in formal meeting or in ceremony meeting. They validate the marriage ceremonial if it is held in a church. The legality of marriage is when the bride and bridegroom promise in front of priest. When they state the

\footnotetext{
${ }^{21}$ Bakhtin, Michael. The Dialogic Imagination...

${ }^{22}$ Swidler, Leonard. What is dialogue..

${ }^{23}$ Jakobson, Roman. Closing Statement: Linguistics and Poetics. In Style in Language. T. (Sebeok, ed. Cambridge, MA: MIT Press, 1960), h. 358

${ }^{24}$ Jakobson, Roman. Closing Statement: Linguistics and Poetics.

${ }^{25}$ Jakobson, Roman. Closing Statement: Linguistics and Poetics.

${ }^{26}$ Jakobson, Roman. Closing Statement: Linguistics and Poetics.
} 
promise they use an institutional language that is language based on church institution.

Marriage in Buginese is influenced by Islam. Buginese's ways of thinking is influenced by the religion. Before marriage they hold meeting in order to discuss the marriage preparation. This meeting is holding in formal way that is in form of cultural ceremony. However, this cultural ceremony reflects Islam's ideology. The validation of marriage is indicated when the bride utters ijab qabul in front of ustaz, parents and witnesses. The words in ijab qabul is words following Islam's way to conduct marriage.

The process of parallelism experiences a development. Former notion of parallelism which discusses the repetition with variation is only in one text delivered by same person. It means that the repetition only occurs in one text by one person. However, the researcher's data shows that the parallelism can occur in different person.

Based on the data in utterances $(59)$ and $(123,124)$, it shows that when the representative of man utters his speech, the utterance is repeated when the representative of woman takes his turn to speech. Because the process of repetition is involving two different speakers, so that this process is called interactional parallelism. The development of parallelism theory occurs in interactional process and this process has not been discussed yet by Jakobson. ${ }^{27}$

\section{E. Conclusions And Suggestions}

There are some conclusions that can be summarized. First, Mappettu ada event is carried out through two representative of man and woman held the ceremonial custom meeting in order to discuss about tanra esso (the day of marriage), sompa (dowry), balanca (money for celebrating the marriage). Second, the discursive interaction that occurs in Mappettu ada event are dialogism and parallelism. The third is the form of parallelism which occurs in Mappettu ada event is interactional parallelism. Lastly, other occurrence in Mappettu ada event is narrating and narrated event, identity construction, and metapragmatic talk.

As suggestion, for those who want to analyze Mappettu ada event, there are still many aspects which has not been discuss yet, especially in Sociolinguistics field.

${ }^{27}$ Jakobson, Roman. Closing Statement: Linguistics and Poetics. 


\section{References}

Abustan \& Alimin. 2008. Adat Perkawinan Masyarakat Bugis. Sulawesi Selatan: Telaga Zam-Zam.

Bakhtin, Michael. 1981. The Dialogic Imagination. C.E.M. Holquist, transl. Austin: University of Texas Press.

Carrington, Victoria. 2009. I write, therefore I am: Texts in the City. Sage Journals. American Political Resources.

Cawung, Rivai. 2001. Analisis Wacana pada Madduta. Makassar: Hasanuddin University.

Cook, Gay. 1989. Discourse. Oxford. Oxford University Press.

Danesi, Marcel \& Peron. 1999. Pesan, Tanda, dan Makna: Buku Teks Dasar Mengenai Semiotika dan Teori Komunikasi. Yogyakarta: Jalasutra.

Halliday, M.A.K. 1985. An Introduction to Functional Grammar. London: NewYork: Edward Arnold

Pelras, Christian. 1996. The bugis.. Cambridge USA: Blackwell Publisher.

Hardianti, 2015. Adat Pernikahan Bugis Bone Desa Tuju-Tuju Kecamatan Kajuara Kabupaten Bone dalam Perspektif Budaya Islam. Makassar: UIN Alauddin.

Hoed, Benny H. 2011. Semiotik \& Dinamika Sosial Budaya. Jakarta: Bambu Community.

Jakobson, Roman. 1960. Closing Statement: Linguistics and Poetics. In Style in Language. T. Sebeok, ed. Cambridge, MA: MIT Press.

Kress, G. (2003). Literacy in The New Media Age. London: Routledge

Marwana, Andi (2016) Dampak Sosial Tradisi "Mappettu ada” Di Desa Cilellang Selatan Kecamatan Mallusetasi Kabupaten Barru. Makassar: FIS UNM.

Mattulada. 1975. Latoa, Suatu Lukisan Analisis terhadap Antropologi Politik Orang Bugis. Yogyakarta: Universitas Gajah Mada Press.

Najamuddin, Andi. 2006. Ada Silappa. Bone.

Pierce, C. Sanders. 1955. Logic as Semiotics:The theory of Sign. In Philosophical writings of Pierce. NewYork: Dover Publications, INC

Putri, Ingrid. 2011. Pemberian Sompa Dalam Sistem Perkawinan Masyarakat Bugis. Makassar: Hasanuddin University.

Swidler, Leonard. 1983 .What is dialogue. Journal of Ecumenical Studies. Dialogue Institute.

Takwa. 2014. Tuturan Ritual Mowindahako Pada Etnis Mekongga. Makassar: Hasanuddin University. 